\title{
EMOTION AND EXCLUSION: Key IDEAS FROM VygotSKY TO REVIEW OUR ROLE In a School with a Cultural Diversity Setting ${ }^{1}$ EMOÇÃO E EXCLUSÁO: IDEIAS-ChAVE DE VYGOTSKY PARA REVER NOSSO PAPEL EM uMA ESCOLA COM UM AMBIENTE DE DIVERSIDADE CULTURAL
}

\author{
Enrique Riquelme MELLA ${ }^{2}$ \\ Gerard LAVOIE ${ }^{3}$ \\ Daniel Quilaqueo RAPIMÁN ${ }^{4}$ \\ Segundo Quintriqueo MILLÁN ${ }^{5}$
}

\begin{abstract}
Research demonstrates that minorities' children diagnosed with Emotional and Behavioural Disorders is overrepresented, being the ethnic minorities the most affected. The diagnostics have resulted in racism and discrimination. This article reflects upon the necessity to develop more integrated and dynamic models of inclusion for the schools. Based on Vygotsky's ideas, a reflexion is done regarding the emotional education in schools, specifically about the need to include -in the teacher formation- the main role of the culture emotional rules in the dynamic of exclusion/inclusion of minorities. The article concludes with proposals to be considered for a culturally sensible vision on inclusion.
\end{abstract}

KEYWORDS: Special Education. Emotional and Behavioural Disorders. Ethnic Minorities. Emotion. Inclusive Education.

RESUMO: pesquisas demonstram que crianças pertencentes a grupos minoritários com diagnóstico de transtornos emocionais e comportamentais estão superrepresentadas, sendo as minorias étnicas as mais afetadas. Os diagnósticos resultaram em racismo e discriminação. Este artigo reflete sobre a necessidade de desenvolver modelos de inclusão mais integrados e dinâmicos para as escolas. Com base nas ideias de Vygotsky, faz-se uma reflexão sobre a educação emocional nas escolas, especificamente sobre a necessidade de incluir - na formaçáo de professores - o papel principal das regras culturais emocionais na dinâmica de exclusão / inclusão de minorias. $\mathrm{O}$ artigo conclui com propostas a serem consideradas para uma visâo culturalmente sensata sobre inclusão.

PALAVRAS-CHAVE: Educação Especial. Transtornos Emocionais e Comportamentais. Minorias Étnicas. Emoção. Educação Inclusiva.

${ }^{1}$ http://dx.doi.org/10.1590/S1413-65382317000200002

Este artículo se enmarca en los proyectos FONDECYT N 1140311 «Socialización emocional en la educación familiar mapuche», FONDECYT Regular No 1140562, "Construcción social del conocimiento educativo mapuche: doble racionalidad y desafíos para una escolarización intercultural», y FONDECYT Regular $\mathrm{N}^{\circ} 1140490$ «Conocimientos geográficos y territoriales mapuches: una base para la formulación de contenidos educativos interculturales pertinentes y contextualizados.

${ }^{2}$ Facultad de Educación, Universidad Católica de Temuco, Temuco, Chile. eriquelme@uct.cl

${ }^{3}$ Université du Québec en Abitibi-Témiscamingue, Quebec, Canadá. Gerard.Lavoie@uqat.ca

${ }^{4}$ Universidad Católica de Temuco, Temuco, Chile. dquilaq@uct.cl

${ }^{5}$ Universidad Católica de Temuco, Temuco, Chile. squintri@uct.cl 


\section{INTRODUCTION}

Emotions are one of the principal ways of learning and understanding about human experiences (GUIDANO, 1991). Each human interaction implies an opportunity to teach and at the same time learn about emotions, especially primary affective experiences with caregivers who give us a starting point about emotional life and abilities (KELLER; OTTO, 2009). They show us a particular way to understand emotional life such as how to regulate, express or hide our emotions as well as read emotions and our ability to attribute emotions (HALBERSTADT et al., 1995). However, the way in which they show us the emotional world is not an isolated one; each early dyadic interaction is located in one particular geographic place and in a particular historical moment (DE LEERSNYDER; MESQUITA; KIM, 2011; VYGOTSKY, 1929). From this point of view, we cannot understand emotional behavior without including the key role that aspects such as the culture, context, language and communication have in the emotional behavior (CHEN; RUBIN, 2011; TSAI; LEVENSON; MCCOY, 2006), in the development of emotional competences (RIQUELME; MONTERO, 2013; RIQUELME et al., 2013), and the children understanding of the social interactions (KELLER; OTTO, 2009).

Basic emotions are considered a part of our biological endowment (LEDOUX, 2003; EKMAN, 2007) and provide us with a common and universal basis. However, it is the culture and the society which allow us to put what we are feeling into words, reason why we feel in a certain way, explain the appropriateness of a given emotion, and the internal and external evaluation of this emotion (POCOCK, 2010; RIQUELME; MUNITA, 2013).

The possibilities to talk about emotions, using a particular emotional vocabulary in a particular context, are also facilitated by the children's capabilities and mediation of the cultural context in which a 'paradigmatic scenario' takes place (DE SOUSA, 1987). A paradigm scenario is understood as a prototypical situation that reflects what is culturally expected in several areas: particularly in the emotional level. Thus, this scenario provides us guidance in the complex world of emotions during the social interaction, for example, the correct interpretation of what happens to us (culturally speaking) in the exploration of the language of our emotions and feelings, as well as exploring the emotional scene which allows us to follow an expectable script of the 'emotional' action.

These paradigm scenarios integrate 'paradigmatic scripts' that enable us to understand the way in which we learn the vocabulary of emotions and therefore, how we learn to identify and classify them. Consequently, we can be witnesses/participants of the construction of the cultural significance of emotions in an individual story, through the analysis of characteristic scripts of different paradigm scenarios (RIQUELME; MUNITA, 2016). In these scenarios and scripts, we can observe and be part of the development of the cultural significance of emotions and different socio-emotional competences in children such as the expression of emotions in a proper way, understanding of one's own and others' emotions, and how to regulate them (DENHAM, 1998, 2007; CHEN; FRENCH, 2008).

However, our emotional competence in a particular scenario does not guarantee success in other paradigm scenarios. A regular context can constitute a paradigmatic scenario with a particular emotional script, and a child can learn how to be competent in the regulation of his emotions in this scenario, but this does not guarantee that these acquired skills are those 
expected in different social and cultural contexts. Therefore, emotional competences developed in a stable paradigm scenario (those that have been functional) might be used in another one, even when this new scenario is based on different scripts, in which those competences are no longer functional (CHEN; FRENCH, 2008). The supposed child's emotional 'incompetence' evidenced in a new setting could then consist in the confusion of scripts, when children fail in the attempt to detect the similarity of the current situation and the original model in which they 'build' the emotion (RODRÍGUEZ, 1998).

School and preschool scenarios give children a new platform to explore and learn about the world and themselves, their friends, peers, and teachers who arise as new referents to whom compare and share their experiences with. As well as, provide a new possibility for the child to develop or restrain their emotional world. In other words, the school shows us new paradigm scenarios where social agents, especially preschools and schools teachers, in the schools can operate as emotional mediators.

In those new schools scenarios some children fit in easily; the emotional scripts are familiar to them and their emotional competences can be developed during the interactions with peers and teachers. From a Vygotskian point of view, this process of internalization of new scripts can be articulated through the Zone of Proximal Development (ZUD), in which children can increase their knowledge and skills with help and scaffolding provided by adults or more advanced peers (RIQUELME; MONTERO, 2013). Nevertheless, there are children whose emotional scripts do not apply to the ideal of emotional behavior in schools, a new paradigmatic scenario of the cultural mainstream and which could lead to the failure of the ZUD process of articulation. Thus, we can observe in one child different attempts to try to fit in a new social and emotional scenario without losing the emotional way by which he already knows the world, trying to apply his emotional competences.

From an external point of view, the child's different attempts could be seen as difficulties to fit in, being labelled and diagnosed with, for example, Emotional and Behavioural Disorders (EBD).

There are many more subtle ways for a child to deal with the mainstream emotional culture, especially when they come from ethnic minorities (FOLEY, 2004) and, at the same time, there are many different ways to deal with the difference from the point of view of schools (CLINE et al., 2002 ; PRIEST et al., 2014). In a global scenario, schools have had an active role in the inclusion processes focusing on a dynamic approach of responding positively to pupil diversity. However, there still is plenty of work to be done, especially when individual differences are seen not as problems, but as opportunities to enrich learning, and when there is work to be done on indigenous contexts (United Nations Educational, Scientific and Cultural Organization [UNESCO], 2005). Seeing the differences as difficulties is even more complex when the mainstream culture over-diagnoses emotional problems in children who belong to minority cultures and have learnt to succeed in emotional scenarios that do not necessarily match with those of the dominant culture (CHENTSOVA-DUTTON; VAUGHN, 2012).

In this line, the inclusion has been traditionally directed to those who present disabilities in the frame of the main idea of 'integration', omitting the dynamic approach of 
responding positively to those children who belong to minorities in an EDUCATION FOR ALL (CLINE et al., 2002).

In this article, a reflection about the idea of inclusion and the necessity to develop more integrated and dynamic models of inclusion for the schools is made. From Vygotsky's central ideas, a reflection about the emotional education in schools is made. The necessity to include -in the teacher formation- the main role of the culture emotional rules in the dynamic of exclusion/inclusion of minorities, particularly ethnic minorities is also discussed.

\section{AbOUT INCLUSION, EMOTIONAL AND BEHAVIOURAL DISORDERS AND MINORITIES}

UNESCO views inclusion as "[...] a dynamic approach of responding positively to pupil diversity and of seeing individual differences not as problems, but as opportunities for enriching learning" (UNESCO, 2005, p.12).

Inclusive education is the object of a broad worldwide consensus in response to the marginalization and social exclusion that still affects many children. It proposes a value or principle that allows every child to be educated in his natural environment, whatever his specific needs are. Over the years, this position has been supported by several international organizations. For example, the meeting of Jomtien in Thailand (UNESCO, 1990) where the idea of Education for all was assented; also the convention in Salamanca, Spain (UNESCO, 1994), where the implementation of this idea in favour of people with special educational needs was operationalized; and finally, the World education forum that was held in Dakar, Senegal (UNESCO, 2000), where an update on worldwide advances in Education for all was provided and a new framework for action was submitted.

Although the principle of inclusive education for all is praiseworthy, putting it into practice however requires a thorough review of the education systems, both politically and legally, as well as a concrete organization of the school and the classroom. Referring to the magnitude of work to accomplish, Mittler (2003, p.1) states: "[...] Inclusion is a long process, a road to travel rather than a destination [...]". This is not a simple process; we cannot ignore the difficulties that responding to the specific needs of some students create to school personnel and the difficulties that those responses create to children. In order to avoid putting these children apart or excluding them by applying special procedures, feasible alternatives must be considered to welcome and encourage the commitment of these students by a change in the scholar system culture that allows us to reflect about our homogenization tendency and our responsibility with ethnic minorities.

Although inclusive education is clearly stated, it is equally clear that some students are still being segregated and neglected. In this regard, it is acknowledged that those with emotional and behavioural disorders (EBD) represent the biggest challenge of inclusive education (REICHER, 2010; STOUTJESDIJK; SCHOLTE; SWAAB, 2012; SIMPSON; MUNDSCHENK, 2012). The Individuals with Disabilities Education Act (IDEA) defines $\mathrm{EBD}$ as a condition exhibiting one or more of the following characteristics over a long period and to a marked degree that adversely affects a child's educational performance:

A) An inability to learn that cannot be explained by intellectual, sensory, or health factors;

B) An inability to build or maintain satisfactory interpersonal relationships with peers and teachers; C) Inappropriate types of behaviour or feelings under normal circumstances; D) A 
general pervasive mood of unhappiness or depression; E) A tendency to develop physical symptoms or fears associated with personal or school problems.

'The term includes schizophrenia. The term does not apply to children who are socially maladjusted, unless it is determined that they have an emotional disturbance' (IDEA Regulations: Part 300 / A / 300.8 / c / 4).

Students labelled with EBD are the most excluded from the regular classroom (HEATH et al., 2004) and educated in special classes or other segregated settings (STOUTJESDIJK et al., 2012). A national study in special education, conducted in the United States, showed that EBD students are precisely the most excluded from the class or school for disciplinary reasons (ACHILLES et al., 2007; BOWMAN-PERROTT et al., 2011).

Vincent, Sprague and Tobin (2012) examined data on disciplinary exclusionary practices of a State in northwestern United States. They reported that students with these difficulties are more removed from the class and for longer periods of time than other students. They also observed that among these students, the American Indian and Alaska Native (AI/ AN) are the most affected by disciplinary action. The strong representation of ethnic minority students suspended or expelled from school is very well documented in research. Krezmien et al. (2006) reported similar findings nationwide. Among the different racial groups, the African American students, followed by Native American students, are the ones mostly affected by measures of exclusion. These researchers also present the alarming finding of the unexpected increase of the students' exclusion rate for American Indian students between 1995 and 2003. IDEA stated, '(C) African-American children are identified as having mental retardation and emotional disturbance at rates greater than their White counterparts' (Statute: TITLE I/A/601/c/12). This observation is probably related with the dropout rate of students AI/AN that increased from $14.5 \%$ in 1997 to $19.3 \%$ in 2007 (AUD et al., 2010).

In 2011, Rescorla et al., compared transcultural number of EBD diagnostic among 11 countries; in this sample North American countries and European countries such as Spain, UK, as well as South American countries such as Peru and Chile were included. In his investigation, Chilean pre-schoolers scored 7.1 points (1 SD) over the omnicultural average, pointing that the mean total problems score of Chile was higher than in all the other evaluated societies (RESCORLA et al., 2011). Unfortunately, although Chile has a large percentage of people who belong to minority cultures, this study did not elaborate a further analysis about EBD diagnostic on indigenous children, and the country however, has not conducted any studies on EDB in cultural or ethnic minorities (see CAQUEO-URÍZAR; URZUA; DE MUNTER, 2014 for a complementary view). Cultural minorities has not been a topic of discussion in a school context that has consistently refused family education of indigenous cultures like the Mapuche, even though this is one of the most representative native people in this country.

The above mentioned could be product of a process of epistemic hierarchical classification respect to what is considered emotionally correct under a moral or social prism, which contributes to a homogenous and colonized goal.

Indeed, only recently cultural identity has begun to be considered as a dimension that should be integrated in the planning of the academic activities of the school. This 
reflects a process of exclusion that, in contexts of cultural diversity, has resulted in racism and ethnic discrimination against Mapuche Students (BECERRA; MERINO; MELLOR, 2015). Nevertheless, racism and discrimination in schools are not exclusive to South American educational system; this has a long history in schooling worldwide.

The disciplinary exclusion remains on the rise in the United States (BOWMANPERROTT et al., 2011), even if research does not confirm its efficiency as a means for responding to students with behavioural difficulties. Instead, a number of adverse consequences are related to this practice. In fact, the cumulative loss of valuable learning time in class contributes to worsen school problems. Through their expulsions, students tend to disengage both academically and from the school itself (ACHILLES et al., 2007), thus increasing their risk of failure and school dropout (VINCENT; SPRAGUE; TOBIN, 2012), and resulting in adverse socio-emotional consequences (OSHER et al., 2010). The disengagement of students gradually extending beyond the school, Vincent, Sprague and Tobin (2012) report the likelihood that they become candidates for the justice system is increased. In minority groups, the exclusion not only results in expulsion from school, in Chile for example, the presence of low socioeconomic status, rurality and belonging to Mapuche ethnicity are also linked to an increase in symptoms associated with mental health (ANTÚNEZ; VINET, 2013).

Summarizing, despite the efforts to adapt the educational policies to the UNESCO statements, for example the Special Educational Needs and Disability Act (2001) in UK, or the IDEA in the United States, besides the suggestions coming from the Organisation For Economic Co-Operation And Development (OLABERRIA, 2016), the research demonstrates that minorities children are overrepresented in those who have been labelled with a EBD diagnostic (STOUTJESDIJK et al., 2012).

There are several reasons trying to explain this huge disproportionality, the poverty hypothesis is one of the most known explanations, and at the same time, one of the most useless. We can see that there are other 'systemic factors' operating under this phenomenon (CODRINGTON; FAIRCHILD, 2012). The advance in the understanding and solution of this problem in schools requires a complex and compressive model. This model must be: a) able to consider de indivisibility of the human experience and learning, b) able to situating the problem in cultural and historical contexts and c) able to include the key role of the mediators in the generation/diagnostic of the problem as well as in the solution (ARTILES et al., 2010).

We argue that the Vygostkian theory provides the principal elements for an integrative view, in particular those related with the emotional regulation and social interaction in schools with students coming from diverse cultures. In this frame, three key concepts are analysed: zone of upcoming development, perezhivanie and obucheniye. 


\section{VYGOTSKY AND THE ROLE OF EMOTIONS IN TEACHING/LEARNING SITUATION}

(Thought) is engendered by motivation, i.e. our desires and needs, our interests and emotions. Behind every thought there is an affective-volitional tendency [...] (VYGOTSKY, 1933/1986, p.252).

Levyth (2008) found that the affective dimension is not really taken into account in the implementation of Vygotsky's work in school context. Note that Vygotsky worked at the very end of his life on the manuscript specifically written on this subject and that the translation of this document in English language, The teaching about emotions: historicalpsychological studies, was available in 1999 (MAHN; JOHN-STEINER, 2002). Cognitive and cultural dimensions are certainly present in the practice of teaching/learning, but this third affective aspect remains to be added to fully grasp Vygotsky' thought. If this addition called for a theoretical review of the central concept of the zone of upcoming development $(Z U D)^{6}$, Nelmes (2003) considers that it also addresses teachers' practice so that their interventions are equally appropriate at the cognitive as well as at the emotional and cultural levels.

We cannot separately consider the intellectual or cognitive aspect and those of affects or emotions. Vygotsky (1934a) is clear on this point: 'among the most basic defects of traditional approaches to the study of psychology has been the isolation of the intellectual from the volitional and affective aspects of consciousness. ${ }^{7}$ (p.47). On the contrary, it is by taking account of their interdependence that he has conceptualized the teaching-learning process, which incorporates both the student who learns and the teacher who teaches, as well as their relationship. The thought of Vygotsky is based on the Russian philosophical tradition, especially on its dynamic input of sociocultural and historical context in which the child is developed. This expanded contextual perspective is at the root of his conception of learning, which is effectively conceived at the interface of the child and its social and cultural milieu. Moreover, it is precisely under this aspect of relation or the child's encounter with his environment that the emotional dimension is understood, what the term perezhivanie that he uses allows us to account.

The word perezhivanie is difficult to translate in English or Spanish. For Vygotsky, this word currently used in the Russian language covers many facets of personal and situational nature which must be seized as entity, as 'an indivisible unity' (1934b). While the language itself tends to split reality into separate units or concepts and the recourse to the rational and linear thinking seeks to link the meaning of things, perezhivanie must be grasp in its complexity and as a whole. Vygotsky associates repeatedly this term to the expression 'emotional experience'. The term thus covers 'the relationship which exists between the child and its environment, the child's emotional experience [perezhivanie], in other words how a child becomes aware of, interprets, [and] emotionally relates to a certain event'8 (VYGOTSKY,1934b, p.304-341).

Vygotsky (1934b) presents the reaction of three children to a difficult family situation. Each child is affected differently because of the way they live it, their own perezhivanie. A same objective situation may indeed 'be interpreted, perceived, experienced or lived through by

${ }^{6}$ The translation zone of proximal development is increasingly questioned in specialized writings. The translation zone of upcoming development better reflects the temporal sequence to which Vygotsky refers when he uses this expression.

${ }^{7}$ Some Vygotsky's writings consulted electronically were not paginated.

${ }^{8}$ The italic form is present in the original text. 
different children in different ways' and lead to different reactions and consequences. Both the way it is lived and experienced emotionally and the cognitive interpretation of each child is therefore determinant. Under Vygotsky's relational conception, the difficult situation of this family cannot be considered as strictly objective or independent but rather through the prism of the emotional experience or respective perezhivanie of each child. Its only reality is perceived, represented and experienced, tinted with what the child is, his personal characteristics and his past experiences in a particular cultural frame and historic moment; paradigmatic scenarios and the specific scripts of each scenario are part of this social construction of the child full experience.

For Vygotsky, perezhivanie is composed of 'all the factors which are related to [its] personality [...], all the features of its character, its constitutional elements, which are related to the event in question' (1934b, p.342).

Among the child characteristics associated with its perezhivanie, Vygotsky identifies specifically the level of development. Indeed, a child perceives, represents to himself and interprets differently the reality that surrounds him depending on his age, his cognitive abilities at a given stage and the development of his thought. Although the environment set up for him can be objectively different, adapted to his age and capabilities, the reality remains, however, fluctuating and takes the form that the child confers to it according to the particularity of his needs and how he is able to understand it. Vygotsky (1934b) is explicit on this point: 'Every age presents the child with an environment which has been organized in a special way, so that the environment, in the purely external sense of the word, keeps changing as the child passes on from one age to another.' (p.339). Thus, in order to seize the central concept of zone of upcoming development (ZUD) for Vygotsky, we must consider all to what perezhivanie refers either the stage of development and the child's abilities, but also his emotional experiences in context.

According to Vygotsky (1934c), the ZUD is the distance between the actual level of development of the child' mental functions as determined by his task-solving abilities and the level of potential development to solve tasks under the direction or assistance of a mediator. Thus defined, the cognitive and social aspects of the thought of Vygotsky are highlighted, which also explain why they received a particular attention in the past. There is indeed questioning on the level of intellectual development and solving tasks or tests, which refer to the cognitive achievement of the child, as well as assistance or guidance of an adult, and social aspect of the ZUD. Regarding this social aspect, in a previous writing on 'the cultural development of the child', Vygotsky (1929) argues that the child goes beyond a strict natural development to engage in the path of cultural development of his psychic functions, this implies the importance or the need for social mediation. Limited to these only two aspects, the ZUD as presented by Vygotsky in this writing (1934c) does not include the dimension of emotions, at least explicitly.

The thesis of Gonzalez (2011) regarding three distinct moments in the development of the thought of Vygotsky helps to explain the lack of attention to the affective or emotional dimension, both in Soviet psychology and for his successors in the Western countries. If his writings of the first (1915-1927) and the third moment (1932-1934) are related to 'his interest in the cognitive-emotional unity of the psyche and the functioning of the psyche as a whole' 
(GONZALEZ, 2011, p.269), those of the second moment (1927-1931) concern specifically his understanding of the higher mental functions and the development of its cultural-historical conception. But, in this second moment 'his references to emotions, fantasy, and imagination which were extensive in the first moment of his work—disappeared' GONZALEZ, 2011, p.268). According to Gonzalez, it is precisely this second moment of his thought that was highlighted or reified by his successors, with the consequence to ignore other fundamental aspects of his work.

'The concept of the [ZDP] addresses the whole person. Human emotions and desires, as Vygotsky contended, are a fundamental part of a complete human being' (LEVYKH, 2008, p. 98)

Levykh (2008) argues that it is wrong to refer to an extended version of the ZUD including the dimension of affects and emotions. According to him, there is no need for such a version in the sense that the conception of Vygotsky already includes this affective dimension. The Russian word obucheniye that he uses covers both aspects of learning and teaching, while the English language considers them separately. By adopting that word, Vygotsky emphasizes the quality of the relationship between teacher and students, as well as the important role of emotions to encourage its establishment. From a dynamic perspective, the concept of ZUD must be understood integrating both aspects of emotional and cognitive order.

The comfort generated by an interrelational context of quality would be a 'solid platform for successful learning' (LEVYKH, 2008 p.92). By its stimulating effect in the child, it would contribute to the expansion of the area of its potential learning or his ZUD. On this point, contrary to the widely diffused idea that development or maturation precedes learning, Vygotsky rather adopts the opposite point of view that learning would pass in the foreground, hence the consecrated formula that learning leads development. Now, in absence of the educational pole and the emotional dimension (nevertheless inherent) in the conception of the ZUD in Vygotsky, this formula appears limited. Levykh, 2008 considers it would be more accurate to broaden its scope by rather saying 'obucheniye leads development' (p. 100).

Vygotsky considers that with the assistance of an adult (or a more advanced peer), a child may go beyond its current level of development. In this regard, Mahn and JohnSteiner (2002) borrow the expression gift of confidence to Jean-Paul Sartre to illustrate how the emotional connection with another person can stimulate this process. Simone de Beauvoir, the woman with whom he shared his life, has certainly contributed to his achievements as a critic of his writings, but she did more by the confidence that she was able to infuse within himself. Sartre has acknowledged explicitly this point: 'You did me a great service. You gave me a confidence in myself that I shouldn't have had it alone' (De Beauvoir, quoted by MAHN; JOHN-STEINER, 2002, p. 6). By the gift of confidence she gave him, he could do his work as a writer confidently, taking the risk of the diffusion of his ideas and exceeding his periods of doubt. It is the same for the ZUD, which, by its emotional component, turns out to be a space of support, affection and trust offered to the student. It is under the effect of such a stimulating context that his ZUD can not only be established and maintained but also expanded. The gift of [the] confidence that the teacher manifests to the student is a sign of a relationship, which is favourable to the obucheniye the entire teaching-learning process, both for the student who receives it and who learns as well as to the teacher who gives it and teaches. 
It is within the context of meaningful and satisfying interpersonal relationships that children are most likely to engage in such processes as imitation and invention, all the while constructing their own understandings of activities and experiences (MALLORY; NEW, 1994, p.328).

Gindis (1995) argues that the concept of ZUD remains absent in the practice of special education. The consultation of the database ERIC (August 26 ${ }^{\text {th }} 2015$ ) also seems to confirm that this is still the case today. Indeed, the combination of descriptors or ZPD or zone of proximal development and special education do not permit to identify any document when the search is performed in the field of the Title and only allows identifying eleven documents when questioned at the scale of the Abstract. In The fundamental problems of defectology, Vygotsky argues that the problem is not the impairment or disability in itself but rather the impact it brings in terms of integration and social functioning of the child. This situation is particularly complicated when the schools tends to see more 'disabilities', emotional problems or a lack of emotional competences in minority students. Hence, an intervention should target not only the child's learning process but, at the same time the social situation in which the difficulties arise, the two poles of the dynamic interaction within the ZUD and perezhivanie.

Vygotsky considers that we are on the wrong track if we only focus on the correction of the deficiency or handicap. According to him, attention should not be limited to the difficulties of the child, but other dynamic aspects of his person must be taken into account in the ZUD interaction. Integral parts of the ZUD of the child and careful observation of these mechanisms help to identify some of his actual understandings and what it is possible to anticipate with assistance and marking out the path of the ovucheniye process. The path as defined is more likely to be beneficial to him as it is already a part of his natural repertoire. The approach that Vygotsky promotes related to schooling is optimistic about its future orientation and positive by its focus on what is acquired, capabilities and potentialities of the child.

Considering the above mentioned, interventions must reflect about the central role that -in the school setting- the teacher has in the obucheniye process. According to Vygotsky's view, we should not consider those that we label as a handicap (for example children with EBD) as fixed states, on the contrary we need to see perezhivanie and the dynamic process activated by the child to deal with a mainstream culture from which a teacher could be the main representative.

Vygotsky therefore adopts a positive approach and writes his work about defectology by putting forward the child's potential on which an intervention can be supported. To this first target we can add a second one, that of social and cultural orientation to infuse to this approach. Indeed, a teacher may seek to help the child to overcome his difficulties caused by his social and cultural environment by providing a warm and welcoming environment and better developmental possibilities. But first, the teacher must have knowledge about his or her own representation of what disabilities are in their cultural frame and about their student's cultural frames to get lines for a sensitive intervention. Teacher's perezhivanie is part of the ovucheniye process, and must be previously acknowledged. In accordance with the socio-

9 It is the same when combined with the descriptors handicap, impairment, disability or deficiency. 
cultural perspective of Vygotsky, it is also encouraged to guide the development of the child in favourable ways to their cultural identification, integration and social participation.

\section{CONClusive REMARKS: TOWARDS A COMPLEX VIEW FOR AN INCLUSIVE EDUCATION IN A CULTURAL DIVERSITY SETTING}

During this essay, we have been trying to expose the necessity to incorporate several reconsiderations that had to be taken in to account, regarding the way in which diagnostics were made in schools. Specifically, with respect to the way in which methods were proposed to reduce what is considered as dysfunctional behaviours in children, whereas though out the past several approaches have been proposed, such as: offering a supportive, responsive, and consistent environment, limiting the problem behaviour, and encouraged positive behaviours.

Historically, strategies have mainly been focused on modifying the students behaviour assuming that they have their own internal problems which must be fixed to improve their academic performance (STOUTJESDIJK; SCHOLTE; SWAAB, 2012). Indeed, we have maintained the illusion of an education focused on the development of higher cognitive functions, keeping aside the emotional processes. The consequences of this explicit exclusion -practically universal in formal education- have been well documented (NEWBERRY; GALLANT; RILEY, 2013).

In social and cultural diverse context, a deeper and more complex vision is required. In the universities, a great challenge is presented by trying to prepare teachers for a multicultural and changing world; this reflection about cultural background must include those who will teach future school teachers. According to the theoretical discussion, there is a necessity to include culture sensitivity in the formation of teachers. Special focus must be made on the proper emotional competences of students in indigenous and intercultural contexts, in order to enrich the formation of all students. The following considerations must be made:

a) A deep analysis of the criteria that the school has assumed to define as appropriate for a child's conduct. The cultural frameworks from which the students behaviour are interpreted and labelled must be considered.

Nothing in society is culture free. Cultural perspective shapes one's individual experience, influences one's worldview, and determines one's values and how they are manifested in the classroom. Biases and prejudices formed by generalizations and stereotypes based on limited personal experience are easily absorbed. A biased cultural perspective can cause you to make inaccurate assumptions about the intelligence and learning abilities of students' (THE ALBERTA TEACHERS’ ASSOCIATION, 2010, p.vii).

This requires analysing our own way of knowing, not only because from these frames we evaluate the appropriateness or inappropriateness of the behaviour of students, but because the students also see in our frames a model that should be incorporated to be successful in the academic dimension, this involves becoming culturally aware and sensitive.

b) A deep analysis must be made taking into account the different school cultural practices criteria, intended to frame the children according to their emotional dimension, 
resulting in racial and homogenous practices. The previously mentioned could be implemented by the school to offer the indigenous children a proper integration to the school and to cultural system of values. Whereas, in indigenous contexts, the children are generally supressed, conscious or unconsciously, in a planned or unplanned manner in order to privilege the homogeny of the euro central occidental sentiment, which results in emotional disagreements between teachers and children to understand the conducts desired by the school.

c) A deep analysis of the knowledge that the school has about the cultures represented by the children in their schools. Supporting our students requires us to obtain cultural background information and become familiar with the cultural variations of behaviours.

If a student displays a behaviour that is common and accepted within his/her cultural group, it should be viewed as 'a difference' from the ways the mainstream society is promoted in the schools; NOT as a 'deficiency' or 'disorder' (MCINTYRE, 1996, p.137).

d) A deep analysis on emotional dimensions is to be put in action with daily interactions, in order to specifically prevent stereotyping and overgeneralizing, i.e.: EBD diagnostics. In practical terms this implies to incorporate educational contents referred to the development of social emotions relevant to the culture, scholar education of ethic and nonethnic minorities to respond to the cultural necessities proper of the social cultural context of the students, which will therefore contribute to the formation of future intercultural citizens which will be able to recognize, accept and respect emotional competences desired to be carried out in different societies and cultures, in order to get over disciplinary discrimination in schools.

Finally, in the epistemological plan, it is essential to include social, cultural and intercultural practices in scholar education in order to provide sense and logic to the emotional conducts to the specific or global contexts in which people interact. We could hence contribute to the transformation of the sense in schools with intercultural and indigenous contexts, in order to get over racist and colonial practices that suppress the proper knowledge that sustains the emotional configuration of the subjects in the cultural and social frame to which they belong.

\section{REFERENCES}

ACHILLES, G.M.; MCLAUGHLIN.; M.J.; CRONINGER, R.G. Sociocultural correlates of disciplinary exclusion among students with emotional, behavioral, and learning disabilities in the SEELS national dataset. Journal of emotional and behavioral disorders, Virginia, v.15, n.1, p.33-45, 2007.

ARTILES, A. J. et al. Justifying and explaining disproportionality, 1968-2008: A critique of underlying views of culture. Exceptional Children, Virginia, v.76, p.279-299, 2010.

AUD, S.; FOX, M. A.; KEWALRAMANI, A. Status and trends in the education of racial and ethnic groups. Washington, DC: Department of Education, National Center for Education Statistics. 2010. Available at: <http://nces.ed.gov/pubs2010/2010015.pdf> Acess on: December $4^{\text {th }} 2014$.

ANTÚNEZ, Z.; VINET, E. V. Problemas de salud mental en estudiantes de una universidad regional chilena. Revista médica de Chile, Santiago, v.141 n.2, p.209-216, 2013. 
BECERRA, S.; MERINO M.; MELLOR, D. Ethnic discrimination against mapuche students in urban high schools in the Araucanía Region, Chile. International Education Studies, Toronto, v.8, n.10, p.96-106, 2015.

BOWMAN-PERROTT, L. et al. Patterns and predictors of disciplinary exclusion over time: An analysis of the SEELS national data set. Journal of emotional and behavioral disorders, Virginia, v.20, n.10, p.1-14, 2011.

CAQUEO-URÍZAR, A.; URZÚA, A.; DE MUNTER, K. Mental health of indigenous school children in Northern Chile. BMC Psychiatry, London, v.14, p.11, 2014.

CHEN, X.; FRENCH, D. Children's social competence in cultural context. Annual Review of Psychology, v.59, p.591-616, 2008.

CHEN, X.; RUBIN, K. (Eds.). Socioemotional development in cultural. New York, NY: Guilford Press, 2011.

CHENTSOVA-DUTTON, Y. E.; VAUGHN, A. Let me tell you what to do: Cultural differences in advice-giving. Journal of Cross-Cultural Psychology, Bellingham, v.43 n.5, p.687-703, 2012.

CLINE, T. et al. Minority ethnic pupils in mainly. White schools. London: Department for Education, 2002.

CODRINGTON, J.; FAIRCHILD H. Special education and the mis-education of African American Children: A call to action. The Association of Black Psychologists Washington, DC, 2012.

DE LEERSNYDER, J.; MESQUITA, B.; KIM, H. Where do my emotions belong? A study of immigrants' emotional acculturation. Personality and Social Psychology Bulletin, Washington, DC, v.37, p.451-463, 2011.

DE SOUSA, R. The rationality of emotion. Cambridge: The MIT Press, 1987.

DENHAM, S. Emotional development in young children. New York: Guilford, 1998.

DENHAM, S. Dealing with feelings: How children negotiate the worlds of emotions and social relationships. Cogniție, Creier, Comportament / Cognition, Brain, Behavior, Cluj Napoca, v.11, n.1, p.148, 2007.

EKMAN, P. Emotions revealed: Recognizing faces and feelings to improve communication and emotional life. 2nd ed. New York: Holt, 2007.

FOLEY, D. El indígena silencioso como una producción cultural. Cuadernos de Antropología Social, Buenos Aires, v.19, p.11-28, 2004.

GINDIS, B. The social/cultural implication of disability: Vygotsky's paradigm for special education. Educational psychologist, v.30, n.2, p.77-81, 1995.

GONZALEZ, F. A re-examination of defining moments in Vygotsky's work and their implications for his continuing legacy. Mind, Culture, and Activity, San Diego, v.18, p.257-275, 2011.

GUIDANO, V. El sí mismo en proceso. Barcelona: Paidós, 1991.

HALBERSTADT, A. G. et al. Self-expressiveness within the family context: Psychometric support for a new measure. Psychological Assessment, Washington, DC, v.7, n.1, p.93-103, 1995.

HEATH, N.L. et al. Inclusion on the final frontier: A model for including children with emotional and behaviour disorders (E/BD) in Canada. International Journal of Inclusive Education, Cambridge, v.8, n.3, p.241-259, 2004. 
KELLER, H.; OTTO, H. The cultural socialization of emotion during infancy. Journal of CrossCultural Psychology, Bellingham, v.40, n.6, p.996-1011, 2009.

KREZMIEN, M.P.; LEONE, P.E.; ACHILLES, G.M. Suspension, race, and disability: Analysis of statewide practices and reporting. Journal of emotional and behavioral disorders, Virginia, v.14, n.4, p.217-226, 2006.

LEDOUX, J. Synaptic self: How our brains become who we are. New York: Penguin Books, 2003.

LEVYKH, M.G. The affective establishment and maintenance of Vygotsky's zone of proximal development. Educational theory, Illinois, v.58, n.1, p.83-101, 2008.

MCINTYRE, T. Guidelines for providing appropriate services to culturally diverse students with emotional and /or behavioral disorders. Behavioral Disorders, v.21, n.2, p.137-144, 1996.

MAHN, H.; JOHN-STEINER, V. The gift of confidence: A Vygotskian view of emotions. In: WELLS, G.; Claxton, G. Learning for Life in the Twenty-First Century: Sociocultural Perspectives on the Future of Education. Cambridge, Massachusetts: Blackwell, 2002.

MALLORY, B.L.; NEW, R.S. Social constructivist theory and principles of inclusion: Challenges for early childhood special education. The journal of special education, Charlotte, v.28, n.3, p.322-337, 1994.

MITTLER, P. Building bridges between special and mainstream services, 2003. Available at: <http:// www.eenet.org.uk/resources/docs/build_bridges.php>. Access on: December $4^{\text {th }} 2014$.

NELMES, P. Developing a conceptual framework for the role of the emotions in the language of teaching and learning. CONFERENCE OF THE EUROPEAN SOCIETY FOR RESEARCH IN MATHEMATICS EDUCATION, Bellaria, Italy, February 28, March 3, 2003. Available at: <http:// www.dm.unipi.it/ didattica/CERME3/proceedings/Groups/TG2/TG2_nelmes_cerme3.pdf >. Access on: March 15th. 2015.

NEWBERRY, M.; GALLANT, A.; RILEY, P. Emotion and schools: Understanding how the hidden curriculum influences relationships, leadership, teaching, and learning. EEUU: Emerald Group Publishing, 2013.

OLABERRIA, E. Chile: Better skills for inclusive growth. OECD Economics Department Working Papers, No. 1290. Paris: OECD Publishing, 2016.

OSHER, D. et al. How can we improve school discipline? Educational researcher, Washington, DC, v.39, n.1, p.48-58, 2010.

POCOCK, D. Emotions as eco systemic adaptations. Journal of Family Therapy, v.32, n.4, p.362-378, 2010.

PRIEST, N. et al. Understanding the complexities of ethnic-racial socialization processes for both minority and majority groups: A 30-year systematic review. International Journal of Intercultural Relations, Florida, v.43, p.139-155, 2014.

REICHER, H. Building inclusive education on social and emotional learning: Challenges and perspectives - a review. International Journal of Inclusive Education, Cambridge, v.14, n.3, p.213-246, 2010.

RESCORLA, L. et al. International comparisons of behavioral and emotional problems in preschool children: Parents' reports from 24 societies. Journal of Clinical Child and Adolescent Psychology : The 
Official Journal for the Society of Clinical Child and Adolescent Psychology, American Psychological Association, Division, Washington, DC, v.40, n.3, p.456-467, 2011.

RIQUELME, E.; MONTERO, I. Improving emotional competence through mediated reading: Short term effects of a children's literature program. Mind, Culture, and Activity, San Diego, v.20, n.3, p.226$239,2013$.

RIQUELME, E.; MUNITA, F. Lectura mediada y escenarios paradigmáticos ficticios. Actas del Seminario Internacional ¿Qué leer? ¿Cómo leer?, Perspectivas sobre la Lectura en la Infancia. Chile. Plan de Fomento Lector del Ministerio de Educación de Chile, 2013. p.349-364.

RIQUELME, E.; MUNITA, F. The mediated reading of children's literature as 'paradigmatic scenario' in the development of emotional competence: Explore the fictional line to change the real script. Psicología, Teoría \& Pesquisa, 2016. (In press).

RIQUELME, E. et al. Reconocimiento facial de emociones y desarrollo de la empatía mediante la lectura mediada de literatura infantil. Cultura y Educación, Madrid, v.25, n.3, p.375-388, 2013.

RODRÍGUEZ, M. Comunicación: Sobre la racionalidad de las emociones [Communication: On the rationality of emotions]. CONGRESO INTERNACIONAL DE LA SOCIEDAD ESPAÑOLA DE FILOSOFÍA ANALÍTICA, 2., 1998. Universidad Complutense de Madrid, 1998.

SIMPSON, R.; MUNDSCHENK, N.A. Inclusion and students with emotional and behavioral disorders. En: BAKKEN J.; OBIAKOR, F.; ROTATORI, A. (Eds.). Advances in special education. Virginia: Emerald Group Publishing Limited, 2012. p. 1-22. v. 23

STOUTJESDIJK, R.; SCHOLTE, E.M.; SWAAB, H. Special needs characteristics of children with emotional and behavioral disorders that affect inclusion in regular education. Journal of emotional and behavioral disorders, Virginia, v.20, n.2, p.92-104, 2012.

TSAI, J.L.; LEVENSON, R.W.; MCCOY, K. Cultural and temperamental variation in emotional response. Emotion, Washington, DC, v.6, n.3, p.484-497, 2006.

THE ALBERTA TEACHERS' ASSOCIATION. Here come everyone, 2010. Available at: < https:// www.teachers.ab.ca/sitecollectiondocuments/ata/publications/human-rights-issues/mon-3\%20 here\%20comes\%20everyone.pdf> Consulted December 4th 2015.

UNESCO. World declaration on education for all: Meeting basic learning needs and agree on the framework for action to meet basic learning needs. Paris: UNESCO, 1990.

UNESCO. The Salamanca statement and framework for action on special needs education. Paris: UNESCO, 1994.

UNESCO. The Dakar framework for action. Education for all: Meeting our collective commitments. Paris: UNESCO, 2000.

UNESCO. Guidelines for inclusion: Ensuring access to education for all. Paris: UNESCO, 2005.

VINCENT, C.; SPRAGUE, J.; TOBIN, T. Exclusionary discipline practices across students' racial/ ethnic backgrounds and disability status: Findings from the pacific northwest. Education and treatment of children, v.35, n.4, p.585-601, 2012.

VYGOTSKY, L.S. The problem of the cultural development of the child. The Pedagogical Seminary and Journal of Genetic Psychology, Worcester, v.36, n.3, p.415-434, 1929.

VYGOTSKY, L.S. On the problem of the psychology of the actor's creative work. In: RIEBER, R.W. (Ed.). The Collected Works of L.S. Vygotsky. New York: Plenum Press, 1932. v. 6. 
VYGOTSKY, L.S. Thought and language. Cambridge (Massachusetts): The MIT Press, 1933/1986.

VYGOTSKY, L.S. Thinking and speech, chapter 1: The problem and the method of investigation. (Edited and translated in part by HANFMANN, E.; VAKAR, G. and in part by MINNICK, N.). Cambridge, Massachusetts: The MIT Press, $1934 \mathrm{a}$.

VYGOTSKY, L.S. The problem of the environment. En: VAN DES VEER, R.; VALSINER, J. The Vygotsky reader. Oxford UK \& Cambridge USA: Blackwell, $1934 \mathrm{~b}$.

VYGOTSKY, L.S. Le problème de l'apprentissage et du développement intellectuel à l'âge scolaire. En: YVON, F.; ZINCHENKO, Y. Vygotsky, une théorie du développement et de l'Éducation: Recueil de textes et commentaires. Moscou: MGU Faculté de psychologie de l'Université d'État de Moscou, 1934c.

Recebido em: 29/01/2017

Reformulado em: 05/05/2017

Aprovado em: 05/05/2017 